DOI https://doi.org/10.36059/978-966-397-175-9/71-91

\title{
THE ROLE OF STATE BUDGET OF UKRAINE IN THE IMPLEMENTATION OF ECONOMIC AND SOCIAL POLICY
}

\section{Mishchenko D. A.}

\section{INTRODUCTION}

One of the most important tool of stabilization and development of the national economy, appliance of current economic and social systems to the changing conditions, particularly the implementation of economic and social policy of the country is the state budget. Considering the inability of the current mechanisms of budgeting policy formulation and implementation to solve the problems of the socioeconomic development of the state at the proper level, it is necessary to develop a new budgetary policy, meant to promote to unlocking the country's potential for development on the basis of financial decentralization and realization of the inner potential of economic advance (self-development); improvement of intergovernmental budgetary relations. The question of theoretical and practical aspects of the role of the state budget in the implementation of the economic and social policy of the state, finding out its place in the system of state regulation of the economy in the conditions of transformation of the national fiscal policy, decentralization and expansion of local authorities is also relevant.

A major contribution to the development of theoretical and methodological foundations of state regulation of socioeconomic processes has been made by such national and foreign scientists as: M. Alexandrova, V. Bazilevich, V. Bodrov, A. Bulatov, O. Vasylyk, V. Vorotin, V. Geyets, V. Grinova, O. Levchenko, Y. Luzan, A. Melnik, O. Mordvinov, A. Muzychenko, V. Oreshin, V. Rossokha, G. Tretyak, N. Ushenko, N. Shiyan and others. In justice to the scientific achievements of scientists, it should be noted that it is still ill-defined and requires an in-depth study of the question of improving the use of the 
budgetary mechanism in the implementation of the economic and social policy of the state.

\section{Analysis of establishment and application of state budget funds}

In the modern period of development of the budget system, the formation of a sufficient amount of state budget revenues and ensuring their efficient application assume special importance. The state budget is an integral part of the budget system of each country and an important tool for implementing the economic and social policy of the state.

The Budgetary code defines the structure of the budget system of Ukraine, which includes the state budget and local budgets. Local budgets are budgets of the Autonomous Republic of Crimea, regional, provincial, and local government budgets, which include budgets of territorial communities of villages, their unions, settlements, cities (including districts in cities), and budgets of united territorial communities.

Budget revenues play an important role in the socioeconomic development of society. Budget revenues, on the one hand, are the result of the distribution of GDP between various participants in the reproduction process, and on the other, are the object of further distribution of value, concentrated in the state hands, because the latter is used for budget establishments of different levels.

In formalizing the financial category ,budgetary resources”, we deem it advisable to pay attention to its objective features, peculiar to any economic system. Thus, budgetary resources are: 1) a product of the seizure of part of the value of a newly created product of society and its distribution and redistribution according to economic, social and political purposes; 2) the basis for the creation of centralized and decentralized budgetary funds; 3 ) an important instrument for regulating the economic relations of society; 4) a specific financial category with stable natural properties, characteristic forms of expression and laws of development, in what connections these relationships are permanently changing.

In the meantime, some scientists narrow down the economic content of the „budgetary resources" category to the level of the state budget. Thus, A. Zagorodniy and G. Vozniuk define these resources as the 
means from which the state budget is formed and which compose a significant part of the centralized financial resources of the state ${ }^{1}$.

Therefore, budgetary resources as a financial category are given considerable attention, while at the same time there is no holistic comprehension of this complex economic concept. Each scientist characterizes the budgetary resources from the standpoint of the tasks of his own research, omitting other important aspects. In addition, the definitions do not specify the purpose of such resources provision.

The Budget Code of Ukraine, the main legislative act in the field of budgetary relations, also lacks formalization of the term "budgetary resources"; in this category it is identified with the concept of "budgetary funds". In the Code, budgetary funds (public funds) are interpreted as appropriated in accordance with the law of budget revenue receipt. In turn, "budget revenues are budget incomes, repayment of loans to the budget, funds from state (local) borrowings, funds from selling stateowned assets (regarding the state budget), repayment of budget funds from deposits, proceeds from the sale / presentation of securities" 2 .

Formation and distribution of budgetary resources, intended for the fulfillment of its functions by the state, is the economic basis for the existence of the latter. At the same time, the status of each resource implies the presence of its properties such as rarity and value. Moreover, the principle of parsimony of economic resources has a comprehensive character, that is why in foreign economic literature it is called fundamental, and the problem of the resource insufficiency is considered as determinative.

In fact, all kinds of economic resources, which are at the disposal of society, are limited and insufficient to meet the full spectrum of human needs, which are generally not limited, unsatisfied, and, moreover, with the development of society, are constantly growing and changing in quantitative and qualitative terms.

\footnotetext{
1 Загородній А.Г., Вознюк Г.Л. Фінансово-економічний словник Львів: Вид-во Львівської політехніки, 2011. 844c.

2 Бюджетний кодекс України від 08 липня 2010 p. № 2456-VI. URL: http://zakon4.rada.gov.ua
} 
It is important to realize exactly what kind of the components of the general fund revenues of the state budget of Ukraine are the most important and how they change over time.

Table 1

Movements of revenues of the General Fund of the State Budget of Ukraine, billion $\mathrm{UAH}^{3}$

\begin{tabular}{|c|c|c|c|c|c|c|}
\hline & \multicolumn{2}{|c|}{$\mathbf{2 0 1 6}$} & \multicolumn{2}{c|}{$\mathbf{2 0 1 7}$} & \multicolumn{2}{c|}{$\mathbf{2 0 1 8}$} \\
\cline { 2 - 7 } & plan & fact & plan & fact & plan & fact \\
\hline Tax revenue & 502,55 & 503,87 & 610,86 & 605,65 & 724,71 & 716,57 \\
\hline Non-tax revenues & 66,14 & 65,19 & 47,47 & 87,39 & 111,41 & 110,40 \\
\hline $\begin{array}{c}\text { Income from capital } \\
\text { operations }\end{array}$ & 0,99 & 0,07 & 0,27 & 0,10 & 0,04 & 0,084 \\
\hline $\begin{array}{c}\text { Revenues from the } \\
\text { European Union, } \\
\text { foreign governments, } \\
\text { international } \\
\text { organizations }\end{array}$ & 3,71 & 2,5 & 0,86 & 1,36 & 1,28 & 1,16 \\
\hline Official transfers & 3,11 & 3,05 & 3,92 & 3,89 & 5,40 & 5,40 \\
\hline Total & 575,63 & 574,66 & 702,02 & 698,41 & 842,85 & 833,62 \\
\hline
\end{tabular}

Table 1 shows income movements of the general fund revenues of the state budget of Ukraine according to the plan and in point of fact. Tax revenues amounting to UAH 502.55 billion in 2016 according to the plan and UAH 503.87 billion in point of fact; they increase by UAH 222.16 billion in 2018 and by UAH 212.7 billion respectively. Non-tax revenues have the same tendency - they grew by UAH 45.27 billion according to the plan and by UAH 45.21 billion in point of fact. Revenues from the European Union, governments of foreign countries, international organizations and at the expense of official transfers were of minor importance.

In order to study the structure of revenues of the general fund of the State Budget of Ukraine, we construct the following table

3 Офіційний сайт Державної казначейської служби України. URL: http://www.treasury.gov.ua/main/uk/index 


\section{Structure of revenues of the General Fund of the State Budget of Ukraine, \%}

\begin{tabular}{|c|c|c|c|c|c|c|}
\hline & \multicolumn{2}{|c|}{$\mathbf{2 0 1 6}$} & \multicolumn{2}{c|}{$\mathbf{2 0 1 7}$} & \multicolumn{2}{c|}{$\mathbf{2 0 1 8}$} \\
\cline { 2 - 7 } & plan & fact & plan & fact & plan & fact \\
\hline Tax revenues & 87,3 & 87,7 & 87,0 & 86,7 & 86,0 & 86,0 \\
\hline Non-tax revenues & 11,5 & 11,3 & 12,3 & 12,5 & 13,2 & 13,2 \\
\hline $\begin{array}{c}\text { Income from capital } \\
\text { operations }\end{array}$ & 0,0 & 0,0 & 0,0 & 0,0 & 0,0 & 0,0 \\
\hline $\begin{array}{c}\text { Revenues from the } \\
\text { European Union, foreign } \\
\text { governments, } \\
\text { international } \\
\text { organizations }\end{array}$ & 0,6 & 0,4 & 0,1 & 0,2 & 0,2 & 0,1 \\
\hline Official transfers & 0,5 & 0,5 & 0,6 & 0,6 & 0,6 & 0,7 \\
\hline Total & 100,0 & 100,0 & 100,0 & 100,0 & 100,0 & 100,0 \\
\hline
\end{tabular}

The share of tax revenues in the structure of the general fund revenues of the state budget of Ukraine remained the largest during the whole period, although it tended to decrease both according to the plan and in point of fact. On the contrary, the share of non-tax revenues slightly increased. The share of revenues from the European Union, foreign governments, international organizations and official transfers, as noted, is insignificant in the structure of general budget revenue of Ukraine.

For the first time a special purpose fund in composition of the state budget appeared in 2000. The reason was the introduction of fiscal records and increased control over the use of funds of budgetary institutions that previously turned out of budget. With the creation of a special purpose budget fund, the former extrabudgetary trust funds have been referred to it ${ }^{4}$.

The amount of the special purpose budget fund of the state budget and the relationship between the sources of income and the directions of use of funds are set annually in the Law on State Budget. The special purpose fund is the resources that are received for a specific purpose and are used for appropriate expenditures at the expense of these revenues.

${ }^{4}$ Боронос В. Г. Особливості реалізації бюджетно-податкової політики України та визначення напрямів ії̈ розвитку. Бізнесінформ. 2012. № 6. С. $145-148$. 
Special fund resources play the role of additional financial support for the implementation of national, social and other functions entrusted to budgetary institutions.

Table 3 shows the indicators that characterize the movements of revenues of the special fund of the state budget of Ukraine.

Table 3

Movements of revenues of the special fund of the state budget of Ukraine, billion UAH

\begin{tabular}{|c|c|c|c|c|c|c|}
\hline & \multicolumn{2}{|c|}{$\mathbf{2 0 1 6}$} & \multicolumn{2}{c|}{$\mathbf{2 0 1 7}$} & \multicolumn{2}{c|}{$\mathbf{2 0 1 8}$} \\
\cline { 2 - 7 } & plan & fact & plan & fact & plan & fact \\
\hline Tax revenues & - & 0,003 & 21,34 & 21,51 & 35,30 & 37,25 \\
\hline Non-tax revenues & 43,91 & 38,45 & 47,47 & 41,18 & 60,27 & 54,28 \\
\hline $\begin{array}{c}\text { Income from capital } \\
\text { operations }\end{array}$ & 1,17 & 0,12 & 0,27 & 0,18 & 0,44 & 0,57 \\
\hline $\begin{array}{c}\text { Revenues from the } \\
\text { European Union, } \\
\text { foreign governments, } \\
\text { international } \\
\text { organizations }\end{array}$ & 1,79 & 1,64 & 0,91 & 0,24 & 1,08 & 0,30 \\
\hline Trust funds & 7,88 & 0,28 & 22,70 & 29,85 & 4,87 & 0,19 \\
\hline Official transfers & 1,15 & 1,12 & 2,12 & 2,07 & 2,03 & 1,90 \\
\hline Total & 55,91 & 41,62 & 94,82 & 95,03 & 103,99 & 94,49 \\
\hline
\end{tabular}

Tax revenues of the special fund of the state budget of Ukraine, which were absent in 2016, but in fact amounted to only UAH 0.003 billion in 2018 they amounted to UAH 35.3 billion according to the plan and UAH 37.25 billion in point of fact. Non-tax revenues also increased, though not so markedly: they increased by UAH 16.36 billion according to the plan and by UAH 15.83 billion in point of fact.

Revenues from the European Union, governments of foreign countries, international organizations and trust funds were insignificant (the exception is 2017, when trust funds received UAH 29.85 billion) in addition, there should be noticeable discrepancies between the planned and actual values by these sources (especially by trust funds). Official transfers increased by UAH 0.88 billion in point of fact and by UAH 0.78 billion according to plan.

In order to study the structure of revenues of the special fund of the state budget of Ukraine, we have made the following table. 
Revenue structure of the special fund of the state budget of Ukraine, \%

\begin{tabular}{|c|c|c|c|c|c|c|}
\hline & \multicolumn{2}{|c|}{$\mathbf{2 0 1 6}$} & \multicolumn{2}{c|}{$\mathbf{2 0 1 7}$} & \multicolumn{2}{c|}{$\mathbf{2 0 1 8}$} \\
\cline { 2 - 7 } & plan & fact & plan & fact & plan & fact \\
\hline Tax revenues & 0,0 & 0,0 & 22,5 & 22,6 & 34,0 & 39,4 \\
\hline Non-tax revenues & 78,5 & 92,4 & 50,1 & 43,3 & 58,0 & 57,4 \\
\hline $\begin{array}{c}\text { Income from capital } \\
\text { operations }\end{array}$ & 2,1 & 0,3 & 0,3 & 0,2 & 0,4 & 0,6 \\
\hline $\begin{array}{c}\text { Revenues from the } \\
\text { European Union, foreign } \\
\text { governments, international } \\
\text { organizations }\end{array}$ & 3,2 & 3,9 & 1,0 & 0,3 & 1,0 & 0,3 \\
\hline Trust funds & 14,1 & 0,7 & 23,9 & 31,4 & 4,7 & 0,2 \\
\hline Official transfers & 2,1 & 2,7 & 2,2 & 2,2 & 2,0 & 2,0 \\
\hline Total & 100,0 & 100,0 & 100,0 & 100,0 & 100,0 & 100,0 \\
\hline
\end{tabular}

The share of non-tax revenues in the revenue structure of the special fund of the state budget of Ukraine remained the largest during the whole period, though it tended to decrease both according to the plan and in point of fact. On the contrary, the share of tax revenues has increased substantially. The share of revenues from the European Union, foreign governments, international organizations, as well as trust funds and official transfers, as noted, is insignificant in the general budget revenue structure of Ukraine, although according to the plan the share of trust funds should be much higher than it was in point of fact (the exception is 2017, when the share of trust fund revenues reached $31.4 \%$ ).

In the conditions of fragile economy of Ukraine and constant deficit of budget funds, mobilization of all state resources and their efficient use becomes necessary.

The performance of its functions by the state depends on the level of their financing and the efficiency of the appliance of the allocated funds. The analysis of the composition, structure of budget expenditures, namely the share of expenditures for the fulfillment of each function of the state in their total amount and in GDP, allows determining which functions are top-priority at each stage of the socioeconomic 
development of the country and whether they are in line with the priorities announced in the budget resolutions' policy.

Successful reform of the public expenditure system is a crucial prerequisite for implementing economic reforms. It must maintain a stable and relatively fast economic growth.

But these reforms should not act as a separate element of state influence on the development of the Ukrainian economy, but should be closely interrelated with reforms in such areas as taxation, establishment of prices, activities of state enterprises, development of social infrastructure of a market economy.

Equally important conditions for success are as follows: restraining government spending within eligible, macroeconomic acceptable limits, strengthening the role of public authorities in stimulating private sector activity, and promoting those capital investments that enhance the distribution and productive efficiency of the Ukrainian economy ${ }^{6}$.

Table 5 shows the indicators that characterize the dynamics of expenditures of the state budget of Ukraine.

In 2018, UAH 45 billion more than in 2016 was spent on general state functions from the State Budget of Ukraine. The considerable amount of expenditures under this article is explained, in particular, by the fact that it includes expenditures for public debt management. In 2018, it was allocated for defense UAH 37.7 billion more than in 2016, for public order, security and the judicial authority - by UAH 45.2 billion more than in 2016. Financing of economic activity expenditures increased by UAH 32.2 billion. Environmental protection was financed in 2018 by UAH 0.5 billion more than in 2016. Expenditures on housing and communal services also increased. Health care expenditures increased by UAH 10.2 billion and expenditures on spiritual and physical development by UAH 5.2 billion. Actual expenditures on education increased by UAH 9.5 billion.

5 Горбунов О.В. Бюджетний менеджмент в системі державного регулювання економіки: дис.. ... к-та екон. наук: 08.00.03. Кропивницький, Центральноукраїнський національний технічний університет, 2018. 246 с.

${ }^{6}$ Рева С.Р. Сучасний стан державного бюджету України. Ефективна економіка. 2014. № 6. URL: http://www.economy.nayka.com.ua/ ?op=1\&z=3112 
Table 5

Movements of expenditures of the State Budget

of Ukraine, billion UAH

\begin{tabular}{|c|c|c|c|c|c|c|}
\hline & \multicolumn{2}{|c|}{$\mathbf{2 0 1 6}$} & \multicolumn{2}{c|}{$\mathbf{2 0 1 7}$} & \multicolumn{2}{c|}{$\mathbf{2 0 1 8}$} \\
\cline { 2 - 7 } & plan & fact & plan & fact & plan & fact \\
\hline $\begin{array}{c}\text { General state } \\
\text { functions }\end{array}$ & 121,95 & 117,9 & 147,02 & 142,4 & 179,28 & 162,9 \\
\hline Defense & 66,69 & 59,3 & 77,83 & 74,3 & 97,79 & 97,0 \\
\hline $\begin{array}{c}\text { Public order, } \\
\text { security and the } \\
\text { judicial authority }\end{array}$ & 72,53 & 71,6 & 0,09 & 87,8 & 123,48 & 116,8 \\
\hline $\begin{array}{c}\text { Economic } \\
\text { activity }\end{array}$ & 35,93 & 31,4 & 51,66 & 47,0 & 74,43 & 63,6 \\
\hline $\begin{array}{c}\text { Environmental } \\
\text { protection }\end{array}$ & 5,35 & 4,7 & 5,25 & 4,7 & 6,14 & 5,2 \\
\hline $\begin{array}{c}\text { Housing and } \\
\text { public utilities }\end{array}$ & 0,038 & 0,012 & 0,04 & 0,016 & 0,41 & 0,3 \\
\hline $\begin{array}{c}\text { Public health } \\
\text { Spiritual and } \\
\text { physical } \\
\text { development }\end{array}$ & 12,82 & 12,4 & 17,33 & 16,7 & 23,34 & 22,6 \\
\hline Education & 38,95 & 34,8 & 46,69 & 41,1 & 50,22 & 44,3 \\
\hline $\begin{array}{c}\text { Social protection } \\
\text { and social } \\
\text { security }\end{array}$ & 152,51 & 151,9 & 145,15 & 144,5 & 164,17 & 163,9 \\
\hline $\begin{array}{c}\text { Inter-budgetary } \\
\text { transfer }\end{array}$ & 196,74 & 195,3 & 279,22 & 272,6 & 304,67 & 298,9 \\
\hline $\begin{array}{c}\text { Total } \\
\text { expenditures }\end{array}$ & 708,57 & 684,7 & 870,49 & 839,2 & 1034,43 & 985,8 \\
\hline
\end{tabular}

Expenditures on social protection and social security show an increase of UAH 12 billion. The amount of intergovernmental transfers increased significantly: from UAH 195.3 billion in 2016 to UAH 298.9 billion in 2018. It should be noted that by all items of expenditures it is observed exceeding the planned indicators over the actually achieved, which indicates that the planned indicators are not fulfilled and the planned work is imperfect, which needs further improvement.

In order to study the structure of expenditures of the state budget of Ukraine, we have made the following table. 
Table 6

Structure of expenditures of the State Budget of Ukraine, \%

\begin{tabular}{|c|c|c|c|c|c|c|}
\hline & \multicolumn{2}{|c|}{$\mathbf{2 0 1 6}$} & \multicolumn{2}{c|}{$\mathbf{2 0 1 7}$} & \multicolumn{2}{c|}{$\mathbf{2 0 1 8}$} \\
\cline { 2 - 7 } & plan & fact & plan & fact & plan & Fact \\
\hline General state functions & 17,21 & 17,22 & 16,88 & 16,97 & 17,33 & 16,5 \\
\hline Defense & 9,41 & 8,67 & 8,94 & 8,86 & 9,45 & 9,8 \\
\hline $\begin{array}{c}\text { Public order, security } \\
\text { and the judicial } \\
\text { authority }\end{array}$ & 10,23 & 10,47 & 10,57 & 10,47 & 11,93 & 11,8 \\
\hline Economic activity & 5,07 & 4,59 & 5,93 & 5,6 & 7,19 & 6,4 \\
\hline $\begin{array}{c}\text { Environmental } \\
\text { protection }\end{array}$ & 0,75 & 0,7 & 0,6 & 0,56 & 0,59 & 0,5 \\
\hline $\begin{array}{c}\text { Housing and public } \\
\text { utilities }\end{array}$ & 0,004 & 0,00 & 0,003 & 0,00 & 0,03 & 0,00 \\
\hline Public health & 1,81 & 1,82 & 1,98 & 1,99 & 2,25 & 2,3 \\
\hline $\begin{array}{c}\text { Spiritual and physical } \\
\text { development }\end{array}$ & 0,71 & 0,72 & 0,94 & 0,94 & 1,01 & 1,02 \\
\hline $\begin{array}{c}\text { Education } \\
\text { Social protection and } \\
\text { social security }\end{array}$ & 5,49 & 5,09 & 5,36 & 4,9 & 4,85 & 4,5 \\
\hline $\begin{array}{c}\text { Inter-budgetary } \\
\text { transfer }\end{array}$ & 27,76 & 22,19 & 16,67 & 17,22 & 15,87 & 16,6 \\
\hline Total expenditures & 100 & 100 & 100 & 100 & 100 & 100 \\
\hline
\end{tabular}

Inter-budgetary transfers had the largest share in the structure of expenditures of the State Budget of Ukraine during the studied period; their share fluctuated within $27.76 \%-32.07 \%$ according to the plan and $28.54 \%-32.48 \%$ in point of fact. Expenditure on social protection and social security and on national functions also had a significant share in the overall structure of expenditures $-16.6 \%$ and $16.5 \%$ respectively in 2018. The share of expenditures on public order, security and the judicial authority in 2018 increased to $11.8 \%$, and the share of expenditures of the State Budget of Ukraine for defense increased to $9.8 \%$.

\section{Improvement of formation and appliance of state budget funds}

According to the Budget Code of Ukraine, budget revenues are tax, non-tax and other non-refundable revenues, which are provided by the legislation of Ukraine (including transfers, payment for administrative services, and revenues from budgetary institutions). All revenues are 
classified as follows: tax revenues; non-tax revenues; income from operations with capital; transfers.

The State Budget revenues of Ukraine are a source of financing the state's expenditures on economic and social orientation, so research into the issues of forming the state budget revenues and their optimization are relevant for each country.

It should be noted that in the current conditions for securing the growth of the state budget revenues, a special significance has the observing tax discipline by taxpayers, in other words timely payment by individuals and legal entities of statutory payments and fees to the state budget. The consolidation of role of tax revenues in the state budget is also possible by improving tax legislation, which will help to avoid insufficient payment of taxes in the state budget; carrying out constant control over the collection of taxes and fees; informing taxpayers of changes in tax legislation, as well as providing explanations on the procedure for applying them and organizing training of taxpayers; strengthening the control by the State Tax Service of Ukraine on the collection of taxes and fees to the budget and enhancement of its role in the legalization of income of entrepreneurs, etc. .

The creation of economic motivation on development of taxable capacity of the country will improve tax revenues, that means, for example, a provision of such social living standards, at which the benefits to the people will outweigh the benefits of tax evasion, and the importance of simplifying the system of taxation and administration of taxes and fees, creating simple and transparent tax rules that will create favourable conditions for economic activity, and as a consequence, it will have a positive effect on economic advance, attracting investment and, consequently, increasing the state budget revenues ${ }^{8}$.

For the purpose of increasing the revenues to the budget it is necessary to expand the presence of domestic products in the markets of

\footnotetext{
${ }^{7}$ Ковальов Ю.В. Виявлення основних причин зменшення надходжень до державного бюджету України. Сталий розвиток економіки. 2012. № 6. С. 322-325.

${ }^{8}$ Крисоватий А. І., Мельник В. М., Кощук Т. В. Сутність та концептуальні основи формування податкової політики в умовах євроінтеграційних процесів. Економіка України. 2016. № 1. С. 35-51.
} 
developed countries by moving from commodity import-dependent to high-tech export-oriented model of economy. The positive effect on the increase of the state budget revenues is a volume reduction of cash payments and an increase in non-cash payments, which will entail the attraction of additional funds to the banking system, and thus will provide a resource for lending to the economy, will contribute to reducing the volume of the shadow economy through legitimization of incomes, fighting corruption and transparentizing of financial flows.

The tendency of recent years allows asserting that the level of budgetary policy effectiveness depends not only on the volume of revenues of the budgetary system, but is mainly determined by the principles and directions of budgetary financing. Despite the steady increase in the revenue side of the budget, there is also a tendency for an increase in the structural (non-cyclical) budget deficit, which is characterized by an increase in government expenditures at a faster rate than an increase in budget revenues.

Expenditures of the state budget of Ukraine are an effective tool for influencing the macroeconomic indicators of the state and the structure of the economy. Public expenditures are a system of financial relations concerning the distribution, redistribution and use of funds of the state's resources for the purpose of carrying out the socioeconomic functions entrusted to it. According to the current Budget Code of Ukraine, budget expenditures are understood to mean funds allocated to the implementation of programs and measures provided by the relevant budget.

The system of budgetary expenditures is an interconnected set of separate elements that characterize the economic relations that arise as a result of the distribution of state funds and ensure the fulfillment of its tasks and functions ${ }^{9}$.

The system of public expenditures has a well-defined subject matter relations related to the mobilization and use of financial resources. The regulatory support of the process of formation and management of public

\footnotetext{
9 Бюджетна система: Навчальний посібник. За заг. ред. В.П. Хомутенко. Одеса: Видавництво Бартєнєва, 2014. 392 с.
} 
expenditures is carried out on the basis of the Constitution of Ukraine, the Budget Code of Ukraine and other laws of Ukraine, government regulations, etc.

Public expenditures are a resource base for public authorities and government in budgetary policy and socioeconomic reforms aimed at ensuring economic growth. Therefore, the formation of the optimal composition and structure of public expenditures in the system of budgetary policy of the state is one of the priority tasks at the present stage of socioeconomic development. Budget policy has four main components as follows: public revenue policy; public expenditures; public debt; budgetary regulation and intergovernmental fiscal relations ${ }^{10}$.

However, in our opinion, the central place to the system of budgetary policy organization takes the public expenditure, since the directions and amounts of their implementation determine the need for the formation of public revenues, the emergence and management of public debt and it is a factor that is taken into account in the redistribution of financial resources between budgets of different levels.

The research of the interrelationships issues of economic growth and the movement of public expenditures and the formation of their optimal ratio is related to determining the effectiveness of budgetary policy implementation.

The economic justification for the mutual influence of the country's economic development and public spending policy is based on the fact that, on the one hand, the country's economic growth rates influence the formation of public expenditure volumes and structures, and on the other, the efficiency of using public financial resources determines the level of socioeconomic development of the country.

Budget financing is a form of centralized allocation of financial resources to legal entities and individuals to carry out budgetary activities. The budgetary financing is carried out according to the following principles: the purposive character of budgetary funds

10 Данилюк М. М. Вплив виконання державного бюджету на макроекономічну стабільність в Україні. Економічний аналіз. 2013. Том 14. № 1. С. 241-247. 
appliance; obtaining maximum effect from the use of budgetary resources on the basis of normalization of costs and a minimum amount of state expenditures for obtaining a result; combination of own, credit and budgetary sources of financing; inconsistency and gratuitous provision of budgetary funds on the free-of-charge basis ${ }^{11}$.

The instruments for the formation and regulation of public expenditures are a set of tools used to fulfill the tasks envisaged by the budgetary policy in the field of public expenditures. They indicate the economic content of a separate set of budgetary relations, such as budgetary norms and regulations, budgetary incentives and intergovernmental transfers, forms and methods of budgetary control, etc.

Thus, budget expenditures play a leading role in the financial support of the needs of socioeconomic development of society. The volume, composition and structure of expenditures are influenced by the volume and nature of the functions of the state, because, in the conditions of commodity-money relations, any state will be able to fulfill its functions to the full, having the necessary amount of budgetary resources.

The study of problems of improving the use of funds of the state budget of Ukraine sparks interest, first of all, because it is the budget that characterizes the level of economic development of the country, and thanks to the proper implementation of the budget process, economic and social stability and a decent standard of living of the population are ensured. Today, in a very difficult and unpredictable time, there are many disputes over the use of the state budget of Ukraine.

Budgetary policy of Ukraine in terms of expenditures is manifested both in the absolute expression of the items of budget expenditures, and in the structure of receipts and spending directions of centralized state funds.

The current state of budget financing is characterized by two key directions: on the one hand, it is a question of occupancy level of the budget revenues, and on the other, the formation of an effective policy of allocation of available funds both in absolute determinations and in the

11 Дорошенко О.О. Особливості формування дохідної частини бюджету України. Ефективна економіка. 2015. № 10. URL: www.economy.nayka.com.ua/pdf/10_2015/66.pdf. 
context of assessing the optimality of its structure. Characterizing the state budget, a necessary task is to analyze its expenditures both in terms of the dynamics of changes in the studied periods and the specific gravity of the individual components.

Moreover, the efficient and rational structure of budget expenditures enables financial support to be provided to the relevant domains of the national economy, which affects the economic growth in the future. The assessment of financing of the expenditures of the state budget of Ukraine allows characterizing the main directions of the budgetary policy, identifying "bottlenecks" in its implementation and formulating a set of measures for its improvement. In order not to complicate the budgetary situation of the government, it is necessary to review and reduce non-essential expenditures. It would be advisable to strengthen the control and accountability for budget legislation compliance. Participants of budgeting process must consciously approach to the budget proposal formulation, be interested in the development of the state, have the facts and realities of the economic and financial situation, and accordingly every figure in the budget must be justified, consistent with the level of economic development of the country.

With the objective of ensuring the enforcement of budgetary targets, they should be planned based on pessimistic economic growth predictions, or set up additional reserves to increase expenditures and / or reduce them in the case of lower than expected economic growth rates. In order to avoid the possible use of incorrect macroeconomic forecasts for the purposes of increasing expenditures over the medium term, in a number of EU countries (for example in Belgium, the Netherlands and Austria) the macroeconomic forecasts are composed by the independent of the government organizations ${ }^{12}$.

Considering the fact that economic activity is one of the most important areas, the effectiveness of which depends directly on the financing of all other functional sections, the amount of its provision is still considered as low. To date, expenditures on social protection and

12 Родіонов В.С. Аналіз дохідної частини бюджету України. Науковий вісник Херсонського державного університету. 2015. № 12 / 3. С. 47 - 49. 
social security far exceed expenditures on economic activity, which, in our opinion, is the reason for slowing down the economic development of the country.

Expenditures on economic activity under the current difficult economic and political conditions require a significant increase in the share of budget expenditures in order to ensure the transition from a budget model of "using up" to an investment-development model.

Considerable volumes of expenditures on the social sector, unfortunately, do not provide a decent standard of living for the population, exceeding expenditures on economic activities, which put the brakes on the economy of the country.

In order to effectively undertake social expenditures, it is necessary to: strictly control the validity of social assistance benefits, introduce social benefit audits and rendering of assistance to those sections of the population that really need it, to an adequate level; develop non-state social (including retirement) insurance; abolish expenditures that are not relevant to social insurance, significantly cut down expenditures of administering the activities of social security funds ${ }^{13}$.

With regard to improving the structure of expenditures for the maintenance of state authorities, it would be advisable to: shrink ranks of the state apparatus and increase its efficiency by motivating civil servants; deregulate and reduce the number of permitting and control procedures, transfer some control and reporting procedures into an automatic form; consistently implement e-governance at national and regional levels; expand the powers of local self-government bodies and „unload” central government bodies from a number of administrative functions.

It is important to improve the institutional environment and the system of analytical tools for forecasting the expenditures of the budget

13 Урядовий портал. Єдиний веб-портал органів виконавчої влади України. URL:https://www.kmu.gov.ua/ua/diyalnist/reformi/efektivne-vryaduvannya/reformaderzhavnih-finansiv 
aimed at strengthening the budgetary policy of the country in the conditions of increasing transformational transitions in the economy ${ }^{14}$.

Particular attention should be paid to the problems associated with improving the budget planning and administration policy implemented in Ukraine at a basis of special-purpose programme. It should help to identify and solve important problems of the country and the regions. But for this, it is necessary to improve the interaction of all participants in the budget process and to respect mutual commitments, starting with setting the strategic goals of the state development and ending with the means of implementation of the smallest budget program in the smallest community.

The special-purpose programme is an approach to budgeting, where the emphasis is made not on the amount of funds needed by the state to perform its functions, but on what results it is planned to achieve using budgetary resources.

The further improvement of the special-purpose programme is an integral component of budgetary reform, which aims at strengthening the responsibility of the chief controllers for their activities, providing the public with the information on the volume and quality of public services, and envisages the enhancing the efficiency of the use of funds by the chief controllers.

According to the results of 2018, the Ministry of Finance of Ukraine has created a legal basis for introducing medium-term budgetary planning, further development of the special-purpose programme. There were improved the individual standards of the Budget Code, governing relations that arise in the process of budget execution, reporting on their implementation and monitoring of compliance with budget legislation, issues of responsibility for its breach have been improved ${ }^{15}$.

One of the fundamental premises for increasing the level of transparency in public finance management is the introduction of

\footnotetext{
${ }^{14}$ Міронова Л.О., Моїсеєнко О.В. Фінансовий потенціал регіону: теоретичний аспект. Вісник ДДФА. 2013. № 2. С. 141-149.

${ }^{15}$ Міщенко Л.О. Оцінка сучасного стану та прогнозування показників місцевих бюджетів в Україні. Ефективна економіка. 2018. № 12. - URL: http://www.economy.nayka.com.ua/ ?op $=1 \& z=6768$
} 
managerial accountability, when managers at different levels are fully aware and responsible for ensuring effective management of public finances.

With the object of further development of the system of public internal financial control, it is necessary to: implement strategic planning, sign internal audit declarations, establish audit committees, etc.; further implementation of the training program for internal auditors, conducting appropriate training activities, working out the possibility of introducing national certification of internal auditors; introduction of a report by state bodies of the Ministry of Finance on the state of internal control organization; improvement of methodological support of internal control and internal audit; conducting external assessments of the quality of internal audit in ministries, other central executive bodies and regional state administrations in order to provide recommendations for improving such activities; automation of internal control and internal audit processes, creation and implementation of an interactive portal on public internal financial control.

\section{CONCLUSIONS}

Although the state finance system in Ukraine has a number of positive features, it still has major deficiencies that worsen the socioeconomic situation and create tangible obstacles to the strengthening of the Ukrainian economy.

Thus, the low efficiency of the system of distribution and use of budgetary funds leads to insufficient financing of the priority tasks facing the state. Another problem is related to fiscal policy, which for a long stretch of time has been unpredictable over the medium term. The consequences of such unpredictability are as follows: taxpayers do not know what taxes will be introduced in the near future; government agencies do not know what amount of finance will be accessible to them in the medium term, and citizens do not know for what purposes budget funds will be allocated and what services from the state they can expect.

The lack of a coherent strategic planning system did not allow the budget planning process to be managed properly and led to a weakening of the links between budget projects and state development priorities. 
These and other factors hamper inflow of investments, lead to ineffective expenditure of scarce resources and public dissatisfaction with government services.

The advancement of mechanism of expenditure planning plays an important role in the state budgetary process as a tool for improving the level of efficiency, effectiveness and transparency of the use of budgetary funds.

The issue of optimizing the budget deficit and budget expenditures in line with the priorities of the country's economic policy, improving the efficiency of the budget institute's use in stimulating domestic demand and growing the economy is of high importance. There is a need to improve the methodological foundations of budget planning in terms of determining the socioeconomic impact of spending over the medium term.

\section{SUMMARY}

The purpose of the study is to determine the role of the state budget in ensuring the socioeconomic development of the country and opportunities for its improvement. It is determined that at the present stage of the development of the budget system, the constitution of a sufficient amount of state budget revenues and ensuring their effective use are of particular importance. The analysis of formation and distribution of budgetary resources intended for the fulfillment by the state of its functions is carried out. It is noted that in order to increase budget revenues, it is necessary to expand the presence of domestic products at advanced markets. It is stressed the need of improving institutional environment and the system of analytical tools of forecasting expenditure budget. The further advancement of Management by Objectives is also an integral component of a budgetary reform. The system enhancement of national internal financial control is also necessary.

\section{REFERENCES}

1. Загородній А.Г., Вознюк Г.Л. Фінансово-економічний словник Львів: Вид-во Львівської політехніки, 2011. 844 с. 
2. Бюджетний кодекс України від 08 липня 2010 р. № 2456-VI. URL: http://zakon4.rada.gov.ua

3. Офіційний сайт Державної казначейської служби України. URL: http://www.treasury.gov.ua/main/uk/index

4. Боронос В. Г. Особливості реалізації бюджетно - податкової політики України та визначення напрямів ії розвитку. Бізнесінформ. 2012. № 6. С. 145 - 148 .

5. Горбунов О.В. Бюджетний менеджмент в системі державного регулювання економіки: дис.. ... к-та екон. наук: 08.00.03. Кропивницький, Центральноукраїнський національний технічний університет, 2018. 246 с.

6. Рева С.Р. Сучасний стан державного бюджету України. Ефективна економіка. 2014. № 6. URL: http://www.economy.nayka.com.ua/?op=1\&z=3112

7. Ковальов Ю.В. Виявлення основних причин зменшення надходжень до державного бюджету України. Сталий розвиток економіки. 2012. № 6. С. 322-325.

8. Крисоватий А. І., Мельник В. М., Кощук Т. В. Сутність та концептуальні основи формування податкової політики в умовах євроінтеграційних процесів. Економіка України. 2016. № 1. С. 35-51.

9. Бюджетна система: Навчальний посібник. За заг. ред. В.П. Хомутенко. Одеса: Видавництво Бартєнєва, 2014. 392 с.

10. Данилюк М. М. Вплив виконання державного бюджету на макроекономічну стабільність в Україні. Економічний аналіз. 2013. Том 14. № 1. С. 241-247.

11. Дорошенко О.О. Особливості формування дохідної частини бюджету України. Ефективна економіка. 2015. № 10. URL: www.economy.nayka.com.ua/pdf/10_2015/66.pdf.

12. Родіонов В.С. Аналіз дохідної частини бюджету України. Науковий вісник Херсонського державного університету. 2015. № 12 / 3. С. $47-49$.

13. Урядовий портал. Єдиний веб-портал органів виконавчої влади України. URL:https://www.kmu.gov.ua/ua/diyalnist/reformi/ efektivne-vryaduvannya/reforma-derzhavnih-finansiv 
14. Міронова Л.О., Моїсеєнко О.В. Фінансовий потенціал регіону: теоретичний аспект. Вісник ДДФА. 2013. № 2. С. 141-149.

15. Міщенко Л.О. Оцінка сучасного стану та прогнозування показників місцевих бюджетів в Україні. Ефективна економіка. 2018. № 12. - URL: http://www.economy.nayka.com.ua/?op=1\&z=6768

\section{Information about the author:} Mishchenko D. A.,

Doctor of Sciences (Public Administration), Professor at the Department of State, Local and Corporate Finance, University of Customs and Finance 2/4, Volodymyra Vernadskoho str., Dnipro, 49000, Ukraine 